Check for updates

Cite this: RSC Adv., 2021, 11, 17658

Received 31st January 2021

Accepted 4th May 2021

DOI: $10.1039 / \mathrm{d} 1 \mathrm{ra00842k}$

rsc.li/rsc-advances

\section{Synthesis, characterization and biological evaluation of dipicolylamine sulfonamide derivatized platinum complexes as potential anticancer agents $\uparrow$}

\author{
Nadini Thushara, (D) a Taniya Darshani, ${ }^{a}$ Sameera R. Samarakoon, (DD ${ }^{b}$ \\ Inoka C. Perera, (D) ${ }^{c}$ Frank R. Fronczek, (D) ${ }^{d}$ W. M. C. Sameera (D) \\ and Theshini Perera (D) *a
}

\begin{abstract}
Three new Pt complexes, $\left[\mathrm{PtCl}_{2}\left(\mathrm{~N}\left(\mathrm{SO}_{2}(2-n a p)\right) d p a\right)\right],\left[\mathrm{PtCl}_{2}\left(\mathrm{~N}\left(\mathrm{SO}_{2}(1-n a p)\right) d p a\right)\right]$ and $\left[\mathrm{PtCl}_{2}\left(\mathrm{~N}\left(\mathrm{SO}_{2} \mathrm{pip}\right) \mathrm{dpa}\right)\right]$, containing a rare 8 -membered ring were synthesized in good yield and high purity by utilizing the ligands $\mathrm{N}\left(\mathrm{SO}_{2}(2-n a p)\right) d p a, N\left(\mathrm{SO}_{2}(1-n a p)\right) d p a$ and $\mathrm{N}\left(\mathrm{SO}_{2}\right.$ pip) dpa, which contain a dipicolylamine moiety. Structural studies of all three complexes confirmed that the ligands are bound in a bidentate mode via $\mathrm{Pt}-\mathrm{N}_{\text {(pyridyl) }}$ bonds forming a rare 8 -membered ring. The intense fluorescence displayed by the ligands is quenched upon coordination to Pt. According to time dependent density functional theory (TDDFT) calculations, the key excitations of $\mathrm{N}\left(\mathrm{SO}_{2}\right.$ (2-nap))dpa and $\left[\mathrm{PtCl}_{2}\left(\mathrm{~N}\left(\mathrm{SO}_{2}\right.\right.\right.$ (1-nap))dpa)] involve the 2-napligand-centered $\pi \rightarrow \pi^{*}$ excitations. While all six compounds have shown antiproliferative activity against human breast cancer cells (MCF-7), the $\mathrm{N}\left(\mathrm{SO}_{2}\right.$ pip)dpa and $\mathrm{N}\left(\mathrm{SO}_{2}(2-\right.$ nap)) dpa ligands and $\left[\mathrm{PtCl}_{2}\left(\left(\mathrm{NSO}_{2}\right.\right.\right.$ pip)dpa)] complex have shown significantly high cytotoxicity, directing them to be further investigated as potential anti-cancer drug leads.
\end{abstract}

\section{Introduction}

Metals play a major role in therapeutic and diagnostic ${ }^{1}$ applications of cancer, prompting the exploration of novel metal organic compounds towards this end. Clinically important organometallic complexes have also been used for the synthesis of effective diagnostic agents. ${ }^{2}$ In fact, $\left[\mathrm{Tc}(\mathrm{CNR})_{6}\right]^{+}$is the first example of an organometallic complex to be clinically used in nuclear medicine. ${ }^{3}{ }^{99 m_{1}} \mathrm{Tc}$ and other short lived isotopes are used as radiopharmaceuticals in disease diagnosis and treatment. ${ }^{4}$ Such radionuclide cationic complexes containing ${ }^{123} \mathrm{I}$ nuclide ${ }^{5}$ and ${ }^{99}{ }^{9} \mathrm{Tc}$ nuclide ${ }^{6}$ are broadly used as potential diagnostic agents while complexes bearing the ${ }^{188}$ Re tricarbonyl core are used as therapeutic agents. ${ }^{7}$ In addition to that, inorganic compounds have found use in chemotherapeutic agents

${ }^{a}$ Department of Chemistry, University of Sri Jayewardenepura, Sri Lanka. E-mail: theshi@sjp.ac.lk

${ }^{b}$ Institute of Biochemistry, Molecular Biology and Biotechnology, University of Colombo, Sri Lanka

${ }^{c}$ Department of Zoology and Environment Sciences, University of Colombo, Sri Lanka ${ }^{d}$ Department of Chemistry, Louisiana State University, Baton Rouge, LA, USA

Institute of Low Temperature Science, Hokkaido University, N19-W8, Kita-ku, Sapporo, Hokkaido 060-0819, Japan

$\dagger$ Electronic supplementary information (ESI) available. CCDC 1867219-1867222. For ESI and crystallographic data in CIF or other electronic format see DOI: 10.1039/d1ra00842k such as the gold-containing antiarthritic drug auranofin and antibacterial, antiviral, antiparasitic and radiosensitizing agents. $^{8}$

The development of modern medicinal inorganic chemistry was stimulated by the discovery of serendipitous cisplatin, the first ever anticancer drug. ${ }^{9,10}$ To address the drawbacks of the severe toxicity ${ }^{9}$ and drug resistance of cisplatin, a large number of cisplatin analogues have been synthesized and evaluated over three generations of platinum drugs (cisplatin, carboplatin and oxaliplatin). ${ }^{11,12} \mathrm{Pt}(\mathrm{II})$ complexes have the advantage of low coordination number, preferential binding to the more limited soft centers in proteins and nucleic acids ${ }^{\mathbf{1 3}}$ and avoid unwanted covalent reactions with nucleotides. ${ }^{14}$ In fact, a key factor explaining why platinum is most useful comes from the ligand exchange kinetics, which for platinum complexes of the type cis$\left[\mathrm{PtX}_{2}(\text { amine })_{2}\right](\mathrm{X}=$ anionic group and amine $=$ primary or secondary amine) are in the order of a few hours, thereby preventing rapid equilibration reactions. ${ }^{15-17}$ Many Pt(II) complexes with ligands having a diene backbone have been synthesized and studied. ${ }^{18}$ For an example, the dansyldiene (DNSH-dienH) ligand which can act as a bidentate, tridentate or quadridentate forms a complex with platinum metal. ${ }^{18} \mathrm{~N}\left(\mathrm{SO}_{2} \mathrm{R}\right) \mathrm{dpa}$ type tridentate ligands and their $\mathrm{Pt}(\mathrm{II})$ compounds with chloride leaving ligands have been synthesized and studied. ${ }^{19}$ These $\mathrm{N}\left(\mathrm{SO}_{2} \mathrm{R}\right) \mathrm{Me}_{n} \mathrm{dpa}(\mathrm{R}=\mathrm{Me}$, Tol; $n=2,4)$ ligands are coordinated in a bidentate fashion in $\left[\mathrm{PtCl}_{2}\left(\mathrm{~N}\left(\mathrm{SO}_{2} \mathrm{R}\right) 3,3^{\prime}, 5,5^{\prime}-\mathrm{Me}_{4} \mathrm{dpa}\right)\right]$ 
complexes, forming a rare eight-membered chelate ring. ${ }^{19}$ The recently reported dinuclear platinum-amine compounds appeared to give rise to DNA binding at two different positions, thereby enhancing the antitumor effect. ${ }^{20}$ Multinuclear platinum drugs that can contain two, three or four Pt centers with both cis and trans configurations have become an attractive strategy to develop potent cisplatin analogues. ${ }^{15}$

Breast cancer is one of the most abundant types of cancer in recent times. Among various types of chronic human diseases, certain types of cancers are widely treated by organometallic complexes. ${ }^{4}$ However, only a few metallopharmaceuticals are available for diagnostic and therapeutic purposes for human breast cancer. ${ }^{21}$

We note that sigma receptors are a specific class of membrane-bound proteins, ${ }^{21}$ classified as $N$-allylnormetazocine link receptors, a type of opiate receptors. ${ }^{22}$ These receptors, their subtypes, transmitters and enzymes are mostly found in the central nervous system, liver, kidney and can serve as attractive targets for radio-selective molecules in oncology. ${ }^{22}$ Sigma receptors are over expressed in vastly dividing cells such as breast, lung and prostate cancer cells ${ }^{23}$ and there is adequate evidence that expression of sigma receptors is down-regulated in quiescent cells. ${ }^{21}$ Furthermore, a few ligands labeled with ${ }^{123} \mathrm{I}^{22}{ }^{99 \mathrm{~m}} \mathrm{Tc},{ }^{23}{ }^{18} \mathrm{~F}^{24}$ have high binding affinity for sigma receptors. Caveliers et al. has reported on the possible use of $N-\left[2-\left(1^{\prime}-\right.\right.$ piperidinyl)ethyl]-3- ${ }^{123}$ I-iodo-4-methoxybenzamide towards the diagnosis of patients with primary breast cancer. ${ }^{21}$ We ourselves have reported on the therapeutic potential of a novel sulfonamide ligand bearing a piperidinyl group and its rhenium complex, $\left[\mathrm{Re}(\mathrm{CO})_{3}\left(\mathrm{~N}\left(\mathrm{SO}_{2}\right.\right.\right.$ pip $\left.\left.) \mathrm{dpa}\right)\right] \mathrm{BF}_{4}$ for therapy of human breast cancer, mainly because these types of compounds preferentially bind with sigma receptors. ${ }^{25}$

Sulfonamide groups are considered as a pharmacophore because they possess many biological activities such as antimicrobial, ${ }^{26}$ anticarbonic anhydrase, ${ }^{27}$ antihypersensitive, ${ }^{28}$ hypoglycemic ${ }^{29}$ activities as well as, most significantly, anticancer activity. ${ }^{30}$ Sulfonamide appended rhenium complexes, for example $f a c$ - $\left[\mathrm{Re}(\mathrm{CO})_{3}\left(\mathrm{NSO}_{2} \mathrm{Rdien}\right)\right] \mathrm{PF}_{6}(\mathrm{R}=\mathrm{dmb}$, tol) have also been proposed as model systems for radiopharmaceuticals. ${ }^{31}$ Symmetrically complexed radiopharmaceuticals derived from dipicolylamine, such as glucosamine- $\mathrm{dpa}^{32}$ have been synthesized and evaluated. Previous studies revealed that the replacement of the amine proton of $\mathrm{N}\left(\mathrm{SO}_{2} \mathrm{R}\right) \mathrm{dpa}$ by various substituents facilitates the formation of metal to nitrogen bonds within the normal range of bond lengths arising exceptional biochemical properties. ${ }^{33}$

The main objective of this study was to synthesize platinum complexes containing dipicolylamine sulfonamides and investigate their activity as anticancer agents. In this study, we specifically opted to synthesize 1-naphthalene sulfonyl, 2naphthalene sulfonyl and piperidine-1-sulfonyl derivatized compounds based on bioactivities reported for these groups; naphthalene derivatized compounds, such as nafcillin, naftifine, tolnaftate and terbinafine, are currently being used as therapeutics $^{\mathbf{3 4}}$ while naphthalene compounds have been reported to exhibit numerous promising pharmaceutical properties, such as anticancer, ${ }^{35-37}$ antimicrobial, ${ }^{38}$ anti- inflammatory $^{39}$ and antineurodegenerative ${ }^{\mathbf{4 0 , 4 1}}$ activities. As noted earlier, piperidinyl derivatized compounds have been used as radiotracers towards targeting breast cancer cells. ${ }^{21}$ Thus, we report on the synthesis and characterization of three novel platinum complexes bearing 1-naphthalene sulfonyl, 2naphthalene sulfonyl and piperidine-1-sulfonyl groups (Scheme 1) and evaluate their cytotoxic activity towards human breast cancer cells.

This study explores the binding of Pt(II) towards dpa derivatized sulfonamides and presents a novel concept in terms of opening up new avenues for bioconjugation of $\mathrm{Pt}$ in rare eight-membered rings. It also explores the differences in coordination mode of ligands containing this scaffold towards platinum and rhenium.

\section{Experimental}

\subsection{Materials and methods}

$\mathrm{K}_{2}\left[\mathrm{PtCl}_{4}\right]$, DMSO, di(2-picolyl)amime, piperidine-1-sulfonyl chloride, 1-naphthalene sulfonyl chloride, 2-naphthalene sulfonyl chloride, analytical grade dioxane, analytical grade methanol, chromasolv water, dichloromethane, anhydrous sodium sulphate and acetonitrile were used as received from Sigma Aldrich, USA. Human breast cancer cell line, MCF-7, was obtained from American Type Culture Collection.

\subsection{NMR measurements}

${ }^{1} \mathrm{H}$ NMR spectra were recorded in DMSO- $d_{6}$ using a Bruker 400 $\mathrm{MHz}$ spectrometer. Peak positions are relative to trimethylsilane (TMS) or solvent residual peak, with TMS as reference. All NMR data were processed with Top Spin 3.2 and Mestre-Nova software.

\subsection{X-ray data collection and structure determination}

Crystal data were collected using a Bruker Kappa APEX-(11) DUO diffractometer. Data were collected at low temperature and data reduction was done on Bruker SAINT and includes absorption by multi scan method, using SHELXS97. Molecular graphics were drawn using ORTEP-3 for windows.

\subsection{UV-visible spectroscopy}

Electronic spectra for ligands and metal complexes were obtained within the spectral range of 200-800 nm using Spectro VIS auto version 3.16, UV-2602 spectrometer. Methanol was

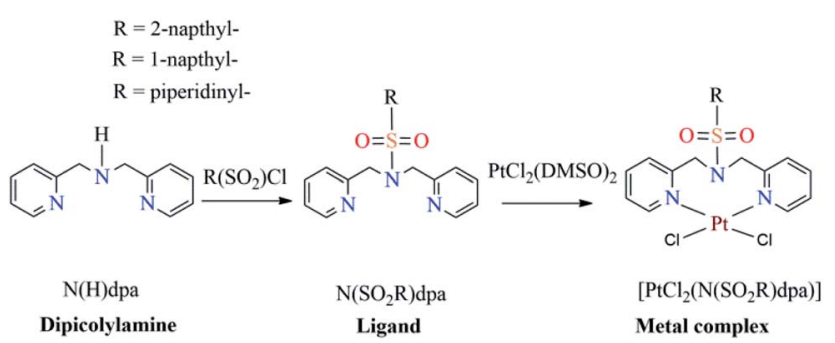

Scheme 1 Synthetic routes for $\mathrm{N}\left(\mathrm{SO}_{2} \mathrm{R}\right) \mathrm{dpa}$ ligands and cis- $\left[\mathrm{PtCl}_{2}(-\right.$ $\left.\left.\mathrm{N}\left(\mathrm{SO}_{2} \mathrm{R}\right) \mathrm{dpa}\right)\right]$. 
used to obtain the spectra with baseline correction. Spectral data were processed with UV WIN software.

\subsection{FTIR analysis}

ATR spectra for ligands and metal complexes were obtained within the spectral range of $4000-600 \mathrm{~cm}^{-1}$ using Thermo Scientific NICOLET iS10 spectrometer. Spectral data were processed with OMNIC software.

\subsection{Fluorometric analysis}

Emission spectra for ligands and metal complexes were obtained in methanol on a Thermo Scientific Lumina spectrophotometer. A $150 \mathrm{~W}$ xenon lamp was used as the excitation source. Spectral data were processed with Luminous software.

\subsection{Melting point determination}

Melting points were manually determined in open capillaries.

\subsection{Synthesis}

In order to synthesize metal complexes, $\left[\mathrm{PtCl}_{2}(\mathrm{DMSO})_{2}\right]$ precursor was prepared as the starting material using $\mathrm{K}_{2}\left[\mathrm{PtCl}_{4}\right]$ according to a known procedure. ${ }^{42}$

2.8.1. $\quad \mathbf{N}\left(\mathrm{SO}_{2}(2-\mathrm{nap})\right)$ dpa ligand. A solution of 2-naphthalene sulfonyl chloride $(2.5 \mathrm{mmol}, 0.572 \mathrm{~g})$ was added to a solution of $\mathrm{N}(\mathrm{H}) \mathrm{dpa}(5 \mathrm{mmol}, 0.92 \mathrm{ml})$ according to a known procedure to obtain $\mathrm{N}\left(\mathrm{SO}_{2}\right.$ (2-nap))dpa ligand. ${ }^{43}$ Brownish yellow colour, plate like crystals suitable for X-ray diffraction were obtained (0.662 g, 68\%). ${ }^{1} \mathrm{H}$ NMR, UV-vis and FTIR data were matched with previously reported data. Melting point: $80.5{ }^{\circ} \mathrm{C}$.

2.8.2. $\left[\mathrm{PtCl}_{2}\left(\mathbf{N}\left(\mathrm{SO}_{2}(2-\mathrm{nap})\right) \mathrm{dpa}\right)\right]$ complex. A solution of $\mathrm{N}\left(\mathrm{SO}_{2}\right.$ (2-nap))dpa $(0.1 \mathrm{mmol}, 0.039 \mathrm{~g})$ in $10 \mathrm{ml}$ of ethanol was added to a solution of $\left[\mathrm{PtCl}_{2}(\mathrm{DMSO})_{2}\right](0.1 \mathrm{mmol}, 0.042 \mathrm{~g})$ in $10 \mathrm{ml}$ of ethanol at room temperature. The reaction mixture was stirred at $50{ }^{\circ} \mathrm{C}$ for 12 hours. Then the resultant precipitate was filtered using a filter paper. The precipitate was taken to dryness. White color powder was obtained $(0.059 \mathrm{~g}, 90 \%)$. UVvis $(\mathrm{MeOH})\left[\lambda_{\max }(\mathrm{nm})\left(\varepsilon \mathrm{M}^{-1} \mathrm{~cm}^{-1}\right)\right]: 228,269 ;$ FT-IR (ATR) $\left(\mathrm{cm}^{-1}\right): 3052(\nu(\mathrm{C}-\mathrm{H})), 1336(\nu(\mathrm{C}-\mathrm{N})), 890(\nu(\mathrm{S}-\mathrm{N})) .{ }^{1} \mathrm{H}$ NMR signals (ppm) in DMSO- $d_{6}$ are $9.27\left(\mathrm{~d}, 2 \mathrm{H}, \mathrm{H6} / 6^{\prime}\right), 8.74(\mathrm{~s}, 1 \mathrm{H})$, $8.24(\mathrm{t}, 1 \mathrm{H}), 8.12(\mathrm{~d}, 1 \mathrm{H}), 8.03(\mathrm{~d}, 1 \mathrm{H}), 7.96\left(\mathrm{t}, 2 \mathrm{H}, \mathrm{H} 4 / 4^{\prime}\right), 7.79-$ $7.75(\mathrm{~m}, 2 \mathrm{H}), 7.74\left(\mathrm{~d}, 2 \mathrm{H}, \mathrm{H} 3 / 3^{\prime}\right), 7.52\left(\mathrm{t}, 2 \mathrm{H}, \mathrm{H} 5 / 5^{\prime}\right), 6.06(\mathrm{~d}$, endo-H), $5.33(\mathrm{~d}$, exo-H). Crystals suitable for single crystal X-ray diffraction were grown by mixing two solutions, each containing $12.5 \mathrm{mM}$ ligand and platinum precursor in acetonitrile. Melting point $>360^{\circ} \mathrm{C}$.

2.8.3. $\quad \mathrm{N}\left(\mathrm{SO}_{2}\right.$ (1-nap))dpa ligand. A solution of 1-naphthalene sulfonyl chloride $(2.5 \mathrm{mmol}, 0.572 \mathrm{~g})$ was added to a solution of $\mathrm{N}(\mathrm{H}) \mathrm{dpa}(5 \mathrm{mmol}, 0.92 \mathrm{ml})$ according to a known procedure to obtain $\mathrm{N}\left(\mathrm{SO}_{2}\right.$ (2-nap))dpa ligand as a brown coloured oil $(0.681 \mathrm{~g}, 70 \%) .{ }^{43}{ }^{1} \mathrm{H}$ NMR, UV-vis and FTIR data matched with previously reported data.

2.8.4. [ $\left.\mathrm{PtCl}_{2}\left(\mathrm{~N}\left(\mathrm{SO}_{2}(1-\mathrm{nap})\right) \mathrm{dpa}\right)\right]$ complex. A solution of $\mathrm{N}\left(\mathrm{SO}_{2}\right.$ (1-nap))dpa (0.1 mmol, $\left.0.039 \mathrm{~g}\right)$ in $10 \mathrm{ml}$ of ethanol was added to a solution of $\left[\mathrm{PtCl}_{2}(\mathrm{DMSO})_{2}\right](0.1 \mathrm{mmol}, 0.042 \mathrm{~g})$ in $10 \mathrm{ml}$ of ethanol at room temperature. The reaction mixture was stirred at $50^{\circ} \mathrm{C}$ for 12 hours. Then the resultant precipitate was filtered using a filter paper and the resulting precipitate was taken to dryness. Yellow-white color powder was obtained (0.050 g, 77\%). UV-vis (MeOH) $\left[\lambda_{\max }(\mathrm{nm})\left(\varepsilon \mathrm{M}^{-1} \mathrm{~cm}^{-1}\right)\right]: 208$, 222, 275; FT-IR (ATR) $\left(\mathrm{cm}^{-1}\right): 3071(\nu(\mathrm{C}-\mathrm{H})), 1326(\nu(\mathrm{C}-\mathrm{N})), 899$ $(\nu(\mathrm{S}-\mathrm{N})) .{ }^{1} \mathrm{H}$ NMR signals (ppm) in DMSO- $d_{6}$ are $9.29(\mathrm{~d}, 2 \mathrm{H}, \mathrm{H6} /$ $\left.6^{\prime}\right), 8.42(\mathrm{~d}, 1 \mathrm{H}), 8.34(\mathrm{~d}, 1 \mathrm{H}), 8.29(\mathrm{~d}, 1 \mathrm{H}), 8.13(\mathrm{~d}, 1 \mathrm{H}), 7.89(\mathrm{t}$, $\left.2 \mathrm{H}, \mathrm{H} 4 / 4^{\prime}\right), 7.76(\mathrm{t}, 1 \mathrm{H}), 7.67(\mathrm{t}, 1 \mathrm{H}), 7.60(\mathrm{t}, 1 \mathrm{H}), 7.55-7.49(\mathrm{~m}$, $4 \mathrm{H}, \mathrm{H} 5 / 5^{\prime}$ and $\left.\mathrm{H} 3 / 3^{\prime}\right), 6.42(\mathrm{~d}$, endo-H), $5.33(\mathrm{~d}$, exo-H). Melting point $>360{ }^{\circ} \mathrm{C}$. Crystals suitable for single crystal X-ray diffraction were grown as described in Section 2.8.2.

2.8.5. $\mathrm{N}\left(\mathrm{SO}_{2}\right.$ pip $)$ dpa ligand. A solution of piperidine-1sulfonyl chloride $(2.5 \mathrm{mmol}, 0.459 \mathrm{~g})$ was added to a solution of $\mathrm{N}(\mathrm{H}) \mathrm{dpa}(5 \mathrm{mmol}, 0.927 \mathrm{ml})$ according to a known procedure to obtain $\mathrm{N}\left(\mathrm{SO}_{2}\right.$ pip)dpa ligand. ${ }^{25}$ Grey color, plate like crystals were obtained $(0.814 \mathrm{~g}, 94 \%)$ and ${ }^{1} \mathrm{H}$ NMR, UV-vis and FTIR data were matched with previously reported data. ${ }^{25}$ Melting point: $77.5^{\circ} \mathrm{C}$.

2.8.6. $\left[\mathrm{PtCl}_{2}\left(\mathbf{N}\left(\mathrm{SO}_{2}\right.\right.\right.$ pip $)$ dpa $\left.)\right]$ complex. A solution of $\mathrm{N}\left(\mathrm{SO}_{2}\right.$ pip$)$ dpa $(0.1 \mathrm{mmol}, 0.035 \mathrm{~g})$ in $10 \mathrm{ml}$ of ethanol was added to a solution of $\left[\mathrm{PtCl}_{2}(\mathrm{DMSO})_{2}\right](0.1 \mathrm{mmol}, 0.042 \mathrm{~g})$ in $10 \mathrm{ml}$ of ethanol at room temperature after which the reaction mixture was stirred at $50{ }^{\circ} \mathrm{C}$ for 8 hours. The resultant precipitate was filtered using a filter paper and dried to yield white color, powder $(0.098 \mathrm{~g}, 60 \%)$. UV-vis $(\mathrm{MeOH})\left[\lambda_{\max }(\mathrm{nm})\left(\varepsilon \mathrm{M}^{-1} \mathrm{~cm}^{-1}\right)\right]$ : 203, 243, 267; FT-IR (ATR) $\left(\mathrm{cm}^{-1}\right): 2940(\nu(\mathrm{C}-\mathrm{H})), 1426(\nu(\mathrm{C}-\mathrm{N}))$, $923(\nu(\mathrm{S}-\mathrm{N})) .{ }^{1} \mathrm{H}$ NMR signals $(\mathrm{ppm})$ in DMSO- $d_{6}$ are $3.12(\mathrm{~d}, 2 \mathrm{H}$, $\mathrm{H}_{\mathrm{a}}$ ), $1.50\left(\mathrm{t}, 3 \mathrm{H}, \mathrm{H}_{\mathrm{b}}\right), 9.25$ (d, 2H, H6/6'), $7.92\left(\mathrm{t}, 2 \mathrm{H}, \mathrm{H} 4 / 4^{\prime}\right), 7.57$ (d, 2H, H3/3'), 7.49 (t, 2H, H5/5'), 6.18 (d, endo- $\mathrm{H}), 5.14$ (d, exo$\mathrm{H})$. Melting point $>360^{\circ} \mathrm{C}$. Crystals suitable for single crystal Xray diffraction were grown as detailed in Section 2.8.2.

\subsection{Computational methods}

Geometry optimizations were performed using density functional theory (DFT) as implemented in the Gaussian 16 program. ${ }^{44}$ The PBE1PBE ${ }^{45}$ density functional, including the Grimme's dispersion ${ }^{46}$ and the Becke-Johnson damping, was employed for ground state calculations. The $\mathrm{SDD}^{47,48}$ basis set and associated effective core potentials were used for Pt, and the det2-TZVP ${ }^{49,50}$ basis sets were applied for the other atoms. The polarizable continuum model (PCM) ${ }^{51-53}$ was used as the implicit solvation model, where methanol $(\varepsilon=32.613)$ was the solvent. Excited-state calculations were performed using the time dependent density functional theory (TDDFT), where the PBE1PBE functional with the Grimme's dispersion and the Becke-Johnson damping, PCM solvation, and the basis sets described above were employed. The nonequilibrium PCM was applied for calculating the singlet vertical excitations, while the equilibrium PCM was used for optimizing the excited states. The "UltraFine" integration grid was applied for TDDFT calculations, where the two-electron integral accuracy parameter was set to 12 . All geometry optimizations were full with no restrictions. Vibrational frequency calculations (at $298.15 \mathrm{~K}$ and $1 \mathrm{~atm}$ ) confirmed that the optimized ground structures were minima (i.e. no imaginary frequencies). 


\subsection{Biological studies}

2.10.1. Anticancer activity. The ligands and corresponding metal complexes were investigated for their cytotoxicity against MCF-7 (breast cancer) cells and MCF-10A (normal human breast) cells. Cells were cultured in 96-well culture plates and exposed to $12.5 \mu \mathrm{g} \mathrm{ml} \mathrm{m}^{-1}, 25 \mu \mathrm{g} \mathrm{ml}{ }^{-1}, 50 \mu \mathrm{g} \mathrm{ml}^{-1}$ and $100 \mu \mathrm{g}$ $\mathrm{ml}^{-1}$ concentrations of ligands and complexes for 24 hours and cytotoxicity was assessed by sulforhodamine B assay. All exposures were carried out in triplicate. Briefly, the cell supernatant was completely removed and washed with phosphate buffer solution. Trichloroacetic acid $(50 \%, 25 \mu \mathrm{l})$ was added on top of fetal bovine serum-free fresh medium $(200 \mu \mathrm{l})$ to make final concentration of $10 \%$ trichloroacetic acid and was incubated at $4{ }^{\circ} \mathrm{C}$ for one hour prior to the SRB assay. The plates were then washed with five washing cycles with water and dried completely. An aliquot of $100 \mu \mathrm{l}$ of $0.4 \%$ sulforhodamine B dissolved in $1 \%$ trichloroacetic acid, was added to each well, and was allowed to stain for 15 minutes. The plates were again washed with five washing cycles to remove unbound dye using $1 \%$ (vol/vol) acetic acid after removing the stain. The protein bound dye was solubilized with trisbase $(10 \mathrm{mM}, \mathrm{pH} 7.5,200 \mu \mathrm{l})$, after air drying. The plates were then shaken for 60 minutes to homogenize the dye solution. The absorbance was then measured at $540 \mathrm{~nm}$ using Synergy HTBioTek microplate reader. The percentage viability was calculated by the equation given below.

$$
\text { Viable cell }(\%)=\frac{\text { absorbance of treated cells } \times 100}{\text { absorbance of untreated cells }}
$$

\section{Results and discussion}

\subsection{X-ray crystallography}

Crystal data and details of the structural refinement for $\mathrm{N}\left(\mathrm{SO}_{2}\right.$ (2-nap))dpa, [ $\mathrm{PtCl}_{2}\left(\mathrm{NSO}_{2}\right.$ (2-nap)dpa)], [ $\mathrm{PtCl}_{2}\left(\mathrm{NSO}_{2}\right.$ (1-nap) $\mathrm{dpa})]$ and $\left[\mathrm{PtCl}_{2}\left(\left(\mathrm{NSO}_{2} \mathrm{pip}\right) \mathrm{dpa}\right)\right]$ are summarized in Table 1. Crystallographic data are deposited with the Cambridge Crystallographic Data Centre under deposition numbers CCDC 1867219, 1867220, 1867221 and 1867222. Crystal data and details of the structural refinement for $\mathrm{N}\left(\mathrm{SO}_{2} \mathrm{pip}\right) \mathrm{dpa}^{25}$ were utilized for comparison purposes. The ORTEP plots of the compounds; $\mathrm{N}\left(\mathrm{SO}_{2}\right.$ (2-nap))dpa, [ $\mathrm{PtCl}_{2}\left(\mathrm{~N}\left(\mathrm{SO}_{2}(2-\right.\right.$-nap) $\left.\left.) \mathrm{dpa}\right)\right],\left[\mathrm{PtCl}_{2}\left(\mathrm{~N}\left(\mathrm{SO}_{2}\right.\right.\right.$ (1-nap)) $\mathrm{dpa})]$ and $\left[\mathrm{PtCl}_{2}\left(\mathrm{~N}\left(\mathrm{SO}_{2} \mathrm{pip}\right) \mathrm{dpa}\right)\right]$ are given in Fig. 1. Key structural parameters of the X-ray structures and fully optimized ground state structures are summarized in Table 2. In general, calculated structures are in agreement with the $\mathrm{X}$-ray structures.

The S-N bond length (1.6277 (6) $\AA$ ) of the $\mathrm{N}\left(\mathrm{SO}_{2}\right.$ (2-nap))dpa ligand is comparable with the $\mathrm{S}-\mathrm{N}$ bond lengths of 1.6194 (11) $\AA$ for $\mathrm{N}\left(\mathrm{SO}_{2}\right.$ pip) $\mathrm{dpa}^{25}$ and 1.602 (9) $\AA$ for $N$-methyltoluene- $p$ sulfonamide and 1.641 (2) $\AA$ for $N, N$-dimethyltoluene- $p$-sulfonamide ${ }^{54}$ However, that has not been depicted by the shortening of $\mathrm{S}-\mathrm{N}$ bond length in $\mathrm{N}\left(\mathrm{SO}_{2}(2-n a p)\right) d p a$ as that of the most common cases. ${ }^{55-57}$ In the ligand, the bond distances between methylene carbon and pyridyl nitrogen (1.4752(9) and 1.471 (9) $\AA$ ), have not deviated from that of the normal range ${ }^{56}$ for $\mathrm{C}-\mathrm{N}$ $\mathrm{sp}^{3}$ bonds. This C6-N2 bond distance (pyridyl $\mathrm{N}$ and methylene carbon) of bidentate $\left[\mathrm{PtCl}_{2}\left(\mathrm{~N}\left(\mathrm{SO}_{2} \mathrm{pip}\right) \mathrm{dpa}\right)\right](1.477$ (4) $\mathrm{A})$ complex is not significantly different to that of tridentate $\left[\operatorname{Re}(\mathrm{CO})_{3}(-\right.$ $\mathrm{N}\left(\mathrm{SO}_{2}\right.$ pip)dpa $\left.)\right]^{+}(1.4615$ (16) $\mathrm{A})$ complex. ${ }^{25}$

In $\left[\mathrm{PtCl}_{2}\left(\mathrm{~N}\left(\mathrm{SO}_{2}\right.\right.\right.$ (1-nap))dpa)], Pt1-N3 and Pt1-N1 (2.029 A, $2.027 \AA$ A) bond distances are similar to Pt-N bond lengths in compounds of the type $\left[\mathrm{PtL}_{2} \mathrm{X}_{2}\right]$ where $\mathrm{L}=$ aniline and $\mathrm{X}=$ halides and nitrites, ${ }^{58}$ illustrating that the interaction between

Table 1 Crystal data and structure refinement for $\mathrm{N}\left(\mathrm{SO}_{2}(2-n a p)\right) d p a,\left[\mathrm{PtCl}_{2}\left(\mathrm{NSO}_{2}(2-n a p)\right) d p a\right],\left[\mathrm{PtCl}_{2}\left(\mathrm{NSO}_{2}(1-n a p)\right) d p a\right]$ and $\left[\mathrm{PtCl}_{2}\left(\mathrm{NSO} \mathrm{O}_{2} \mathrm{pipdpa}\right)\right]$

\begin{tabular}{lllll}
\hline Crystal data & $\mathrm{N}\left(\mathrm{SO}_{2}(2\right.$-nap) $) \mathrm{dpa}$ & {$\left[\mathrm{PtCl}_{2}\left(\mathrm{~N}\left(\mathrm{SO}_{2}(2\right.\right.\right.$-nap $\left.\left.\left.)\right) \mathrm{dpa}\right)\right]$} & {$\left[\mathrm{PtCl}_{2}\left(\mathrm{NSO}_{2}(\right.\right.$ 1-nap $\left.\left.) \mathrm{dpa}\right)\right]$} & {$\left[\mathrm{PtCl}_{2}\left(\left(\mathrm{NSO} \mathrm{N}_{2}\right.\right.\right.$ pip $\left.\left.) \mathrm{dpa}\right)\right]$} \\
\hline Empirical formula & $\mathrm{C}_{22} \mathrm{H}_{19} \mathrm{~N}_{3} \mathrm{O}_{2} \mathrm{~S}$ & $\mathrm{C}_{22} \mathrm{H}_{19} \mathrm{Cl}_{2} \mathrm{~N}_{3} \mathrm{O}_{2} \mathrm{PtS}$ & $\mathrm{C}_{22} \mathrm{H}_{19} \mathrm{Cl}_{2} \mathrm{~N}_{3} \mathrm{O}_{2} \mathrm{PtS}$ & $\mathrm{C}_{17} \mathrm{H}_{22} \mathrm{Cl}_{2} \mathrm{~N}_{4} \mathrm{O}_{2} \mathrm{PtS}$ \\
$M_{\mathrm{r}}$ & 389.46 & 655.45 & 655.45 & 612.43 \\
Crystal description & Lath, colorless & Needle, colorless & Lath, colorless & Needle, yellow \\
Crystal system & Monoclinic & Monoclinic & Monoclinic & Monoclinic \\
Space group & $P 21 / c$ & $C 2 / c$ & $C 2 / c$ & $I 2 / a$ \\
Crystal size $(\mathrm{mm})$ & $0.48 \times 0.31 \times 0.07$ & $0.26 \times 0.06 \times 0.02$ & $0.30 \times 0.10 \times 0.02$ & $0.16 \times 0.10 \times 0.04$ \\
Temperature $(\mathrm{K})$ & 90 & 100 & 100 & 90
\end{tabular}

Unit cell dimensions

$a(\AA)$
$b(\AA)$
$c(\AA)$
$\beta(\mathrm{deg})$
$V\left(\AA^{3}\right)$
$Z$
$R\left[F^{2}>2 \sigma\left(F^{2}\right)\right]$
w $R\left(F^{2}\right)$
Data/parameters
Radiation type
Radiation wavelength $(\AA)$
Abs coeff $/ \mu\left(\right.$ mm $\left.^{-1}\right)$
$2 \theta$ max $($ deg $)$

$20.8714(8)$
$5.6704(2)$
$17.1989(6)$
$114.2072(18)$
$1856.49(12)$
4
0.035
0.102
$9447 / 253$
$\mathrm{Mo} \mathrm{K} \alpha$
0.71073
0.20
74.2

$25.9376(10)$
$9.6371(3)$
$17.6498(6)$
$97.188(4)$
$4377.1(3)$
8
0.030
0.070
$6705 / 371$
$\mathrm{Mo} \mathrm{K} \alpha$
0.71073
6.78
61.2

$26.7076(7)$

$8.7572(2)$

$18.7201(4)$

91.356 (1)

4377.10 (18)

8

0.037

0.080

8404/398

Mo K $\alpha$

0.71073

6.78

66.6

\begin{tabular}{|c|}
\hline $17.5316(5)$ \\
\hline $9.5135(2)$ \\
\hline $24.2020(9)$ \\
\hline $91.872(2)$ \\
\hline $4034.4(2)$ \\
\hline 8 \\
\hline 0.040 \\
\hline 0.077 \\
\hline $11296 / 244$ \\
\hline Mo K $\alpha$ \\
\hline 0.71073 \\
\hline 7.35 \\
\hline 77.2 \\
\hline
\end{tabular}




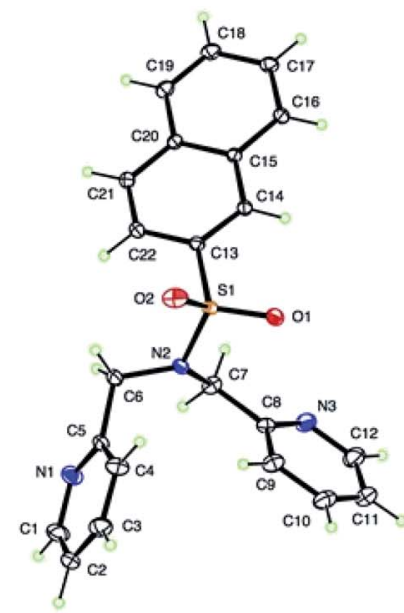

(a)

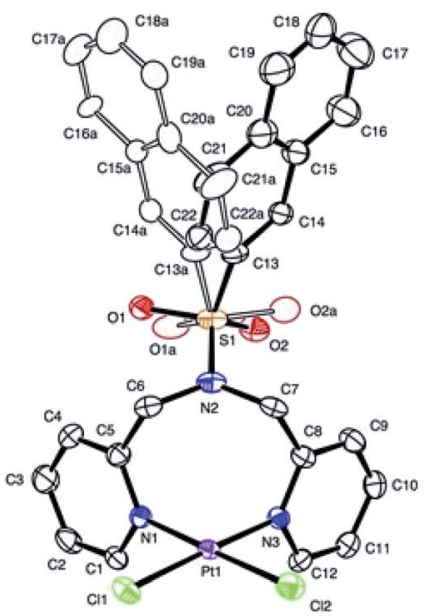

(b)

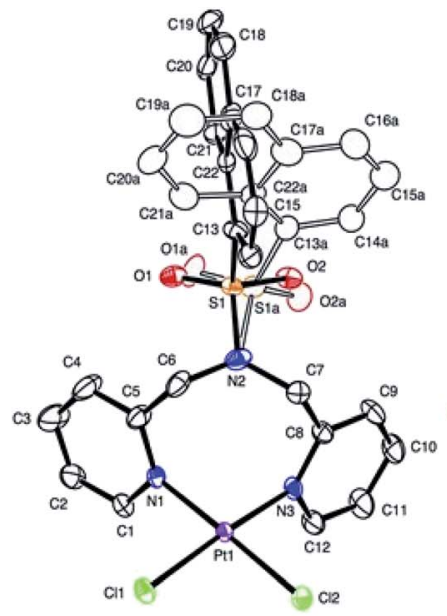

(c)

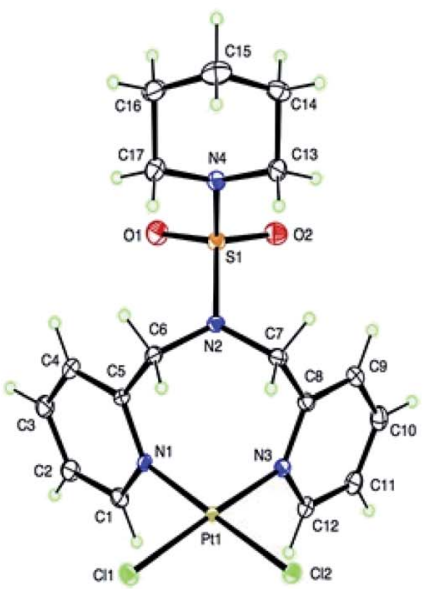

(d)

Fig. 1 ORTEPs of $\mathrm{N}\left(\mathrm{SO}_{2}(2-n a p)\right) d p a(a)$, $\left[\mathrm{PtCl}_{2}\left(\mathrm{~N}\left(\mathrm{SO}_{2}(2-n a p)\right) d p a\right)\right]$ (b), $\left[\mathrm{PtCl}_{2}\left(\mathrm{~N}\left(\mathrm{SO}_{2}(1-n a p)\right) d p a\right)\right]$ (c) and $\left[\mathrm{PtCl}_{2}\left(\mathrm{~N}\left(\mathrm{SO}_{2} \mathrm{pip}\right) \mathrm{dpa}\right)\right]$ (d). Thermal ellipsoids are drawn with $50 \%$ probability with naphthyl disorder shown in (b) and (c).

the new ligand and Pt is strong. The Cl1-Pt1-Cl2 angle (91.79 (4)) is the highest angle around Pt atom because of the high repulsion of lone pairs of the two chlorine atoms. The obtained N1-Pt1-N3 bond angle is $90.05^{\circ}$ (11) and there is no significant change in bond angles of atoms in pyridyl ring except endo nitrogen atom upon complex formation. The $\mathrm{S}-\mathrm{O}$ bond distances of these tridentate ligands are somewhat similar to

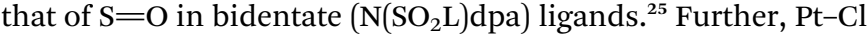
bonds are in the range of normal bond lengths ${ }^{55}$ and provide evidence that there is no change of $\mathrm{Pt}-\mathrm{Cl}$ bond after complexation. The bond angle of Cl1-Pt1-Cl2 $\left(91.77^{\circ}\right.$ (4)) of the $\left[\mathrm{PtCl}_{2}\left(\mathrm{~N}\left(\mathrm{SO}_{2}(1-\mathrm{nap})\right) \mathrm{dpa}\right)\right]$ complex is fairly similar to that of $\left[\mathrm{PtCl}_{2}\left(\mathrm{~N}\left(\mathrm{SO}_{2}\right.\right.\right.$ (2-nap))dpa)] complex. The bond length of $\mathrm{S} 1-\mathrm{C} 13 \mathrm{~A}$ of the $\left[\mathrm{PtCl}_{2}\left(\mathrm{~N}\left(\mathrm{SO}_{2}(1-\mathrm{nap})\right) \mathrm{dpa}\right)\right]$ complex is $1.770 \AA$ and is

Table 2 Selected bond distances $(\AA)$ and bond angles $\left(^{\circ}\right)$ of $\left[\mathrm{PtCl}_{2}\left(\mathrm{~N}\left(\mathrm{SO}_{2}(2-n a p)\right) d p a\right)\right],\left[\mathrm{PtCl}_{2}\left(\mathrm{~N}\left(\mathrm{SO}_{2}(1-n a p)\right) d p a\right)\right]$ and $\left[\mathrm{PtCl} l_{2}\left(\mathrm{~N}\left(\mathrm{SO}_{2} \mathrm{pip}\right) \mathrm{dpa}\right)\right]$

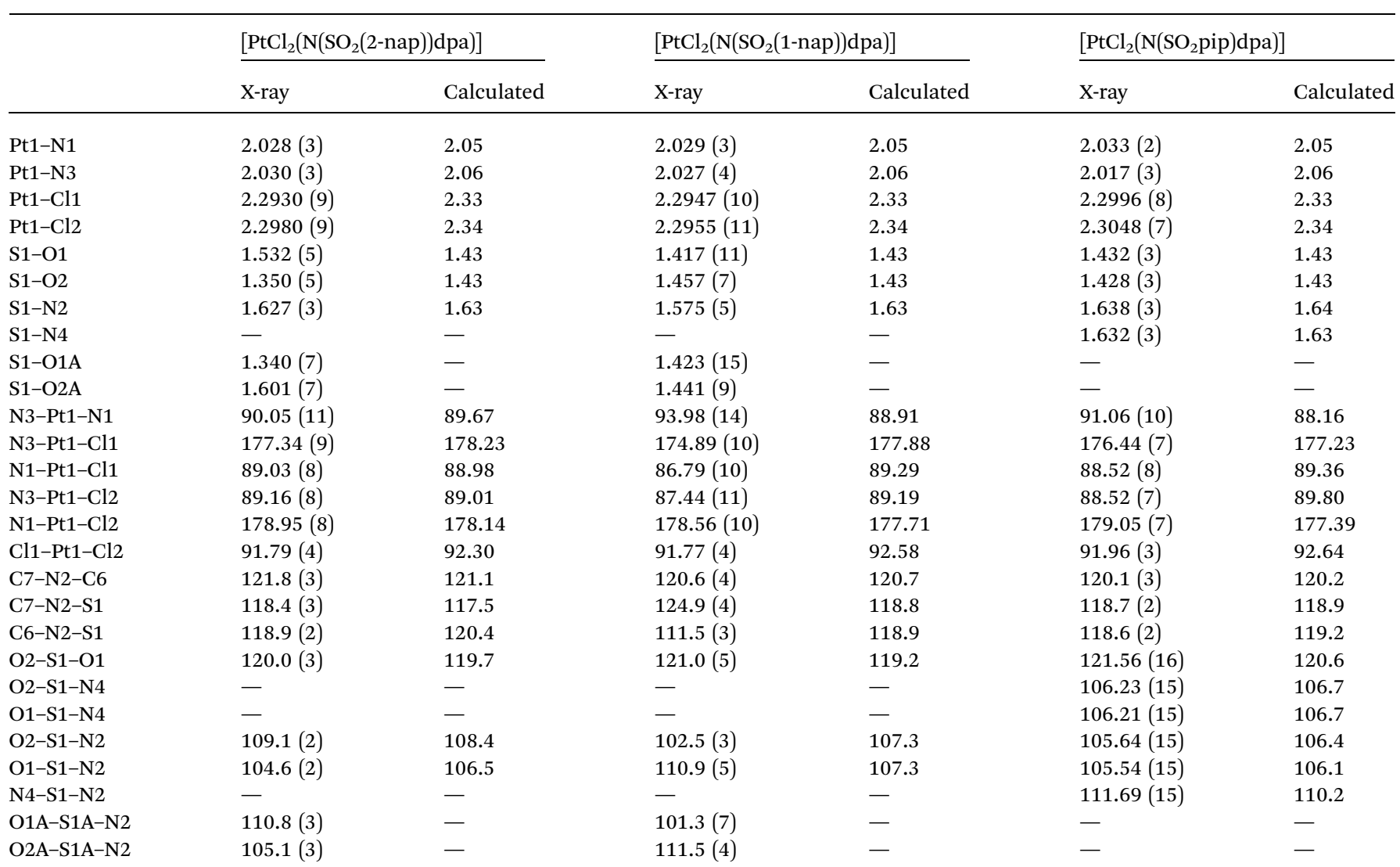


Table 3 Comparison of ${ }^{1} \mathrm{H}$ NMR shifts (ppm) of dipicolylamine units of ligands and complexes in DMSO- $d_{6}$

\begin{tabular}{llllll}
\hline Compound & $\mathrm{H} 6 / 6^{\prime}$ & $\mathrm{H} 5 / 5^{\prime}$ & $\mathrm{H} 4 / 4^{\prime}$ & $\mathrm{H} 3 / 3^{\prime}$ & $-\mathrm{CH}_{2}$ \\
\hline $\mathrm{N}\left(\mathrm{SO}_{2}(2-\mathrm{nap})\right) \mathrm{dpa}$ & $8.31(\mathrm{~d})$ & $7.15(\mathrm{t})$ & $7.63(\mathrm{t})$ & $7.28(\mathrm{~d})$ & $4.60(\mathrm{~s})$ \\
{$\left[\mathrm{PtCl}_{2}\left(\mathrm{~N}\left(\mathrm{SO}_{2}(2-\mathrm{nap})\right) \mathrm{dpa}\right)\right]$} & $9.27(\mathrm{~d})$ & $7.52(\mathrm{t})$ & $7.96(\mathrm{t})$ & $7.74(\mathrm{~d})$ & $6.06(\mathrm{~d}), 5.33(\mathrm{~d})$ \\
$\mathrm{N}\left(\mathrm{SO}_{2}\left(1-\mathrm{nap}_{2}\right) \mathrm{dpa}\right.$ & $8.35(\mathrm{~d})$ & $7.18(\mathrm{t})$ & $7.58(\mathrm{t})$ & $7.13(\mathrm{~d})$ & $7.72(\mathrm{~s})$ \\
{$\left[\mathrm{PtCl}_{2}\left(\mathrm{~N}\left(\mathrm{SO}_{2}(1-\mathrm{1})\right.\right.\right.$} & $7.49(\mathrm{t})$ & $7.89(\mathrm{t})$ & $7.55(\mathrm{~d})$ & $6.42(\mathrm{~d}), 5.32(\mathrm{~d})$ \\
{$\left[\mathrm{PtCl}_{2}\left(\mathrm{~N}\left(\mathrm{SO}_{2}\right.\right.\right.$ pip)dpa)$\left.)\right]$} & $9.29(\mathrm{~d})$ & $7.49(\mathrm{t})$ & $7.92(\mathrm{t})$ & $7.57(\mathrm{~d})$ & $6.18(\mathrm{~d}), 5.14(\mathrm{~d})$
\end{tabular}

higher than that of $\left[\mathrm{PtCl}_{2}\left(\mathrm{~N}\left(\mathrm{SO}_{2}\right.\right.\right.$ (2-nap) $)$ dpa $\left.)\right]$ complex. These $\left[\mathrm{PtCl}_{2}\left(\mathrm{~N}\left(\mathrm{SO}_{2}(2\right.\right.\right.$-nap) $\left.\left.) \mathrm{dpa}\right)\right]$ and $\quad\left[\mathrm{PtCl}_{2}\left(\mathrm{~N}\left(\mathrm{SO}_{2}\right.\right.\right.$ (1-nap) $\left.\left.) \mathrm{dpa}\right)\right]$ complexes show disorder in which sulfur atom has bonded in two different angles to the central nitrogen atom of dipicolylamine group. The two conformers are present in unequal amounts of $56: 44$.

For the $\left[\mathrm{PtCl}_{2}\left(\mathrm{~N}\left(\mathrm{SO}_{2}\right.\right.\right.$ pip $\left.\left.) \mathrm{dpa}\right)\right]$ complex, the structural data revealed that the $\mathrm{S}-\mathrm{O}$ bond lengths (Table 2) are similar to that of $\mathrm{S}=\mathrm{O}$ in $\mathrm{SO}_{2}(1.43 \AA) .{ }^{54}$ Since the $\mathrm{O}-\mathrm{S}-\mathrm{O}$ angle is as wide as to 121.56 (16) $\AA$ and the other angles around sulfur atom are slightly smaller in the range of $106.10-108.17 \AA$ (Table 3 ) than the ideal tetrahedral angle $\left(109.5^{\circ}\right)$, the sulfonyl moiety represents a distorted tetrahedral arrangement around the $\mathrm{S}$ atom.

\section{2. ${ }^{1} \mathrm{H}$ NMR analysis}

The newly synthesized platinum complexes, $\left[\mathrm{PtCl}_{2}\left(\mathrm{~N}_{(} \mathrm{SO}_{2}(2-\right.\right.$ nap))dpa)], $\left[\mathrm{PtCl}_{2}\left(\mathrm{~N}\left(\mathrm{SO}_{2}\right.\right.\right.$ (1-nap))dpa) $]$ and $\left[\mathrm{PtCl}_{2}\left(\mathrm{~N}\left(\mathrm{SO}_{2} \mathrm{pip}\right) \mathrm{dpa}\right)\right]$ were characterized by ${ }^{1} \mathrm{H}$ NMR spectroscopy in DMSO- $d_{6}$ at 298 $\mathrm{K}$. All the peaks were assigned related to the structure of metal complex, based on the chemical shifts, splitting patterns as well as the integration of corresponding peaks. Peaks related to the residual solvents were also identified..$^{59}{ }^{1} \mathrm{H}$ NMR data for the ligands utilized in this study have been previously reported. ${ }^{25,43}$ Therefore, the signals related to the platinum complexes were assigned accordingly. ${ }^{1} \mathrm{H}$ NMR spectra for all compounds are depicted in Fig. 2. Comparison of ${ }^{1} \mathrm{H}$ NMR shifts (ppm) of dipicolylamine units of ligands and complexes in DMSO- $d_{6}$ is reported in Table 3. In the ${ }^{1} \mathrm{H}$ NMR spectrum of $\mathrm{N}\left(\mathrm{SO}_{2}\right.$ (2-nap)) $\mathrm{dpa}$, the aromatic region (7.66-8.13 ppm) is crowded with signals due to magnetically inequivalent protons present in 2-

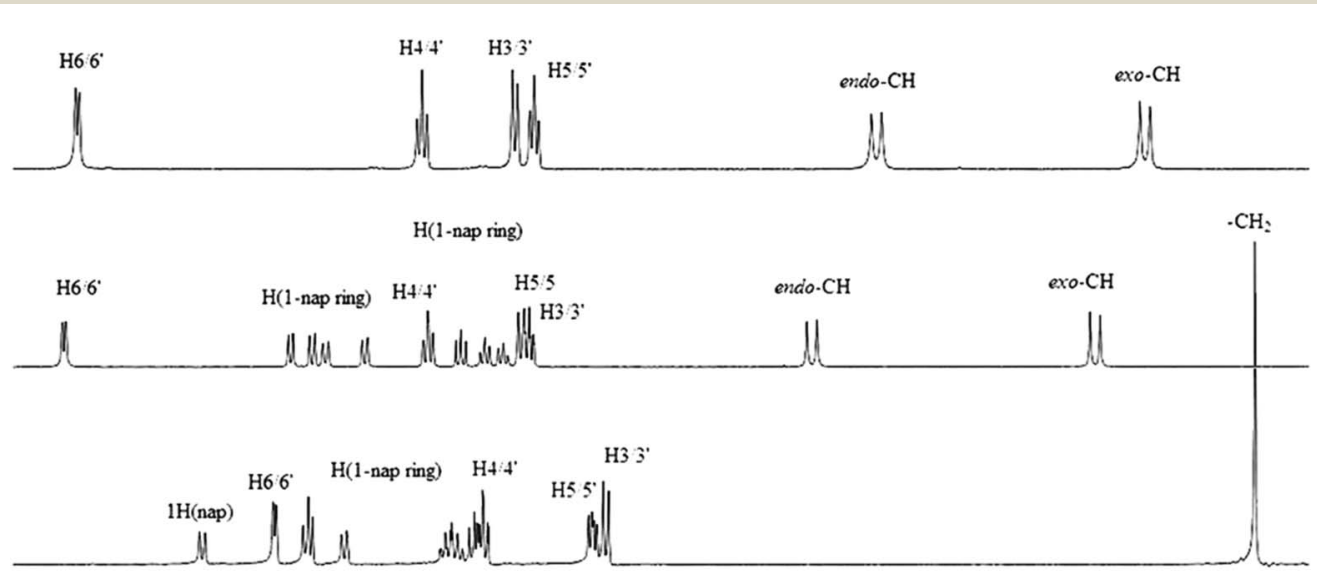

(e)

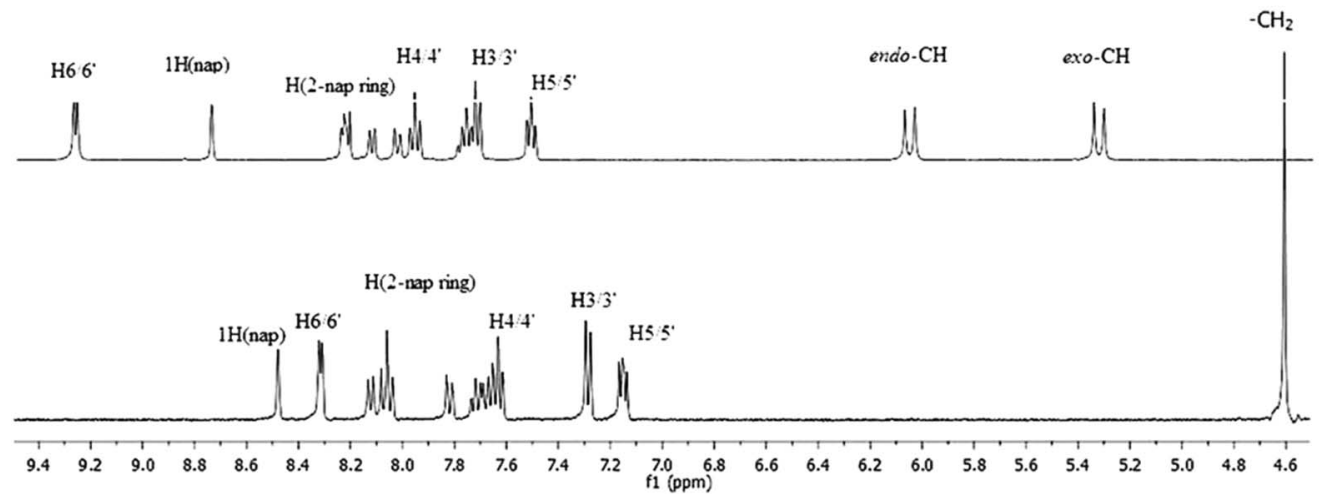

(b)

(a)

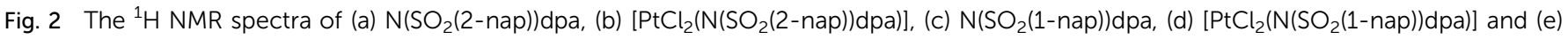
$\left[\mathrm{PtCl}_{2}\left(\mathrm{~N}\left(\mathrm{SO}_{2} \mathrm{pip}\right) \mathrm{dpa}\right)\right]$ in DMSO- $d_{6}$ at $298 \mathrm{~K}$. 
naphthalene group of the ligand. The signal at $7.63 \mathrm{ppm}$ corresponds to the $\mathrm{H} 4 / 4^{\prime}$ proton that is in the para position of the pyridyl nitrogen. Then in the range of $7.66 \mathrm{ppm}$ to $8.13 \mathrm{ppm}$, 2-naphthalene ring protons can be identified according to the previously reported data for the naphthalene ring. ${ }^{60}$ Within that region, the proton attached to $\mathrm{C} 14(1 \mathrm{H}$ nap in Fig. 2) at $8.47 \mathrm{ppm}$ can be clearly identified due to the fact that it is a singlet and is the most deshielded proton in the naphthalene ring. Two protons in each methylene group are sterically similar. Hence, their apparent magnetic equivalence is depicted in ${ }^{1} \mathrm{H}$ NMR spectra by a singlet found at $4.60 \mathrm{ppm}$.

In the $\left[\mathrm{PtCl}_{2}\left(\mathrm{~N}\left(\mathrm{SO}_{2}(2-n a p)\right) d p a\right)\right]$ complex, the peak attributed to methylene protons has split into two doublets $(6.06 \mathrm{ppm}$ and $5.33 \mathrm{ppm}$ ) due to magnetic inequivalence and are shifted downfield. Upon coordinating to $\mathrm{Pt}$, the $\mathrm{H} 6 / \mathrm{6}^{\prime}$ doublet has moved downfield depicting coordination of N1 and N3 to Pt. Furthermore, the proton (attached to $\mathrm{C} 14)$ of $\left[\mathrm{PtCl}_{2}\left(\mathrm{~N}\left(\mathrm{SO}_{2}(2-\right.\right.\right.$ nap))dpa)] appears as a singlet at $8.74 \mathrm{ppm}$.

In a ${ }^{1} \mathrm{H}$ NMR spectrum of the $\mathrm{N}\left(\mathrm{SO}_{2}\right.$ (1-nap))dpa ligand, 1naphthalene ring protons can be identified in the range of $7.65 \mathrm{ppm}$ to $8.21 \mathrm{ppm}$. Similar to $\mathrm{N}\left(\mathrm{SO}_{2}(2\right.$-nap))dpa, the proton of 1-naphthalene ring (attached to C14, Fig. 1) at $8.58 \mathrm{ppm}$ can be clearly identified. Two protons of methylene group are sterically similar. Therefore a singlet for those methylene protons was found at $4.72 \mathrm{ppm}$ (Fig. 2). Methylene protons of $\left[\mathrm{PtCl}_{2}\left(\mathrm{~N}\left(\mathrm{SO}_{2}\right.\right.\right.$ (1-nap))dpa)] complex has split into two doublets (6.42 ppm and $5.32 \mathrm{ppm}$ ) due to magnetic inequivalence and are shifted downfield. Upon coordinating to Pt, the H6/6 doublet and $1 \mathrm{H}$ singlet of $\left[\mathrm{PtCl}_{2}\left(\mathrm{~N}\left(\mathrm{SO}_{2}(1-n a p)\right) \mathrm{dpa}\right)\right]$ have moved downfield (9.29 ppm and $8.74 \mathrm{ppm}$, respectively).

In the $\left[\mathrm{PtCl}_{2}\left(\mathrm{~N}\left(\mathrm{SO}_{2} \mathrm{pip}\right) \mathrm{dpa}\right)\right]$ complex, a higher downfield shift $(0.77 \mathrm{ppm})$ is observed $v s .0 .39 \mathrm{ppm}$ for the rhenium tricarbonyl complex bearing the same ligand ${ }^{25}$ showing the greater inductive of Pt vs. Re. A similar pattern was observed for Pt $v s$. Re complexes carrying the naphthyl derivatives. ${ }^{43}$

For all the signals in the ligand upon coordination to Pt, significant downfield chemical shifts are observed (Table 3). These chemical shifts provide a strong evidence for the formation of metal complex. Downfield chemical shifts are due to inductive effect resulting from the direct $\mathrm{Pt}-\mathrm{N}$ bonds which are formed between Pt metal and $\mathrm{N}$ atoms of the pyridyl ring.

\subsection{FTIR analysis}

As evident from literature, the short absorption band at $3052 \mathrm{~cm}^{-1}$ represents the asymmetric stretching vibrations of $\mathrm{C}-\mathrm{H}$ bonds in aromatic ring whereas the short absorption peaks around $2900 \mathrm{~cm}^{-1}$ are attributed to the $\mathrm{C}-\mathrm{H}$ symmetric stretching vibrations in aliphatic systems in $\mathrm{N}\left(\mathrm{SO}_{2}\right.$ (2-nap))dpa ligand and its $\left[\mathrm{PtCl}_{2}\left(\mathrm{~N}\left(\mathrm{SO}_{2}(2-n a p)\right) \mathrm{dpa}\right)\right]$ complex. The spectra exhibited the decrease of intensities of the bonds at $1426 \mathrm{~cm}^{-1}$ to $1608 \mathrm{~cm}^{-1}$ which may be attributed to the $\mathrm{C}=\mathrm{C}$ groups in the naphthalene ring. Consequently, the stretching vibrational peak due to $\mathrm{C}=\mathrm{N}$, in the pyridyl ring may be present in the range between $1426 \mathrm{~cm}^{-1}$ to $1590 \mathrm{~cm}^{-1}$. The absorption peaks at $928 \mathrm{~cm}^{-1}\left(\mathrm{~N}\left(\mathrm{SO}_{2}\right.\right.$ (2-nap))dpa), $890 \mathrm{~cm}^{-1}\left(\left[\mathrm{PtCl}_{2}\left(\mathrm{~N}\left(\mathrm{SO}_{2}\right.\right.\right.\right.$ (2-nap)) $\mathrm{dpa})]), 920 \mathrm{~cm}^{-1}$ (N(SO $\left.\left.(1-n a p)\right) \mathrm{dpa}\right), 899 \mathrm{~cm}^{-1}\left(\left[\mathrm{PtCl}_{2}\left(\mathrm{~N}\left(\mathrm{SO}_{2}(1-\right.\right.\right.\right.$ nap))dpa)] and $923 \mathrm{~cm}^{-1}\left(\left[\mathrm{PtCl}_{2}\left(\mathrm{~N}\left(\mathrm{SO}_{2} \mathrm{pip}\right) \mathrm{dpa}\right)\right]\right)$ are due to $\mathrm{S}-\mathrm{N}$ stretching vibrational modes for sulfonamide groups. Most of the ligand peaks also appear in the spectra of new complexes. The strong peak at $1334 \mathrm{~cm}^{-1}$ and $1332 \mathrm{~cm}^{-1}$ were attributed to S-C stretching vibrations of the bond between $\mathrm{S}$ atom of sulfonyl group and the $\mathrm{C}$ atom of naphthalene group of $\mathrm{N}\left(\mathrm{SO}_{2}\right.$ (2-nap))dpa and $\left[\mathrm{PtCl}_{2}\left(\mathrm{~N}\left(\mathrm{SO}_{2}\right.\right.\right.$ (2-nap))dpa)], respectively.

Similar to $\mathrm{N}\left(\mathrm{SO}_{2}\right.$ (2-nap))dpa, the short absorption band at $3071 \mathrm{~cm}^{-1}$ represents the asymmetric stretching vibrations of $\mathrm{C}-\mathrm{H}$ bonds in aromatic ring of 1-naphthalene. $\mathrm{C}=\mathrm{C}$ groups in the naphthalene ring exhibits peaks at $1590 \mathrm{~cm}^{-1}$ and $1473 \mathrm{~cm}^{-1}$. The stretching vibrational peak due to newly formed $\mathrm{S}-\mathrm{C}$ may be present at $1276 \mathrm{~cm}^{-1}$. Most of the other peaks are similar to the previously discussed ligand, $\mathrm{N}\left(\mathrm{SO}_{2}(2-n a p)\right) d p a$. According to the results obtained, most of the ligand peaks also appear in the spectrum of new $\left[\mathrm{PtCl}_{2}\left(\mathrm{~N}\left(\mathrm{SO}_{2}\right.\right.\right.$ (1-nap))dpa) complex. The peaks at $1457 \mathrm{~cm}^{-1}$ and $1598 \mathrm{~cm}^{-1}$ are due to $\mathrm{C}=\mathrm{C}$ stretching vibrations of naphthalene ring. The peaks at $1276 \mathrm{~cm}^{-1}$ and $1132 \mathrm{~cm}^{-1}$ were attributed to S-C stretching vibrations of $\mathrm{N}\left(\mathrm{SO}_{2}(1-n a p)\right) d p a$ and $\left[\mathrm{PtCl}_{2}\left(\mathrm{~N}\left(\mathrm{SO}_{2}(1-n a p)\right) \mathrm{dpa}\right)\right]$, respectively. The obtained sharp peaks at $1157 \mathrm{~cm}^{-1}$ and $1134 \mathrm{~cm}^{-1}$ of metal precursor due to the S-Pt bond were not observed in the spectrum of $\left[\mathrm{PtCl}_{2}\left(\mathrm{~N}\left(\mathrm{SO}_{2}\right.\right.\right.$ pip $\left.\left.) \mathrm{dpa}\right)\right]$ complex providing evidence that $\mathrm{N}\left(\mathrm{SO}_{2}\right.$ pip)dpa ligand and metal precursor have completely reacted to give the product of $\left[\mathrm{PtCl}_{2}\left(\mathrm{~N}\left(\mathrm{SO}_{2} \mathrm{pip}\right) \mathrm{dpa}\right)\right]$.

\subsection{UV-visible analysis}

UV-visible spectra of $\mathrm{N}\left(\mathrm{SO}_{2}\right.$ (2-nap))dpa, $\left[\mathrm{PtCl}_{2}\left(\mathrm{~N}\left(\mathrm{SO}_{2}\right.\right.\right.$ (2-nap)) dpa)], N( $\left.\mathrm{SO}_{2}(1-n a p)\right) d p a,\left[\mathrm{PtCl}_{2}\left(\mathrm{~N}\left(\mathrm{SO}_{2}\right.\right.\right.$ (1-nap))dpa) $]$ and $\left[\mathrm{PtCl}_{2}(-\right.$ $\mathrm{N}\left(\mathrm{SO}_{2}\right.$ pip)dpa $\left.)\right]$ in methanol are given in Fig. 3 .

UV-visible data for $\mathrm{N}\left(\mathrm{SO}_{2}\right.$ pip)dpa was previously reported. ${ }^{25}$ Kohn-Sham frontier molecular orbitals of the ground state optimized structures of $\mathrm{N}\left(\mathrm{SO}_{2}(2-n a p)\right) \mathrm{dpa}$ and $\left[\mathrm{PtCl}_{2}\left(\mathrm{~N}\left(\mathrm{SO}_{2}(2-\right.\right.\right.$ nap))dpa)] complex are shown in Fig. 4 (see Fig. $\mathrm{S} 2 \dagger$ for the

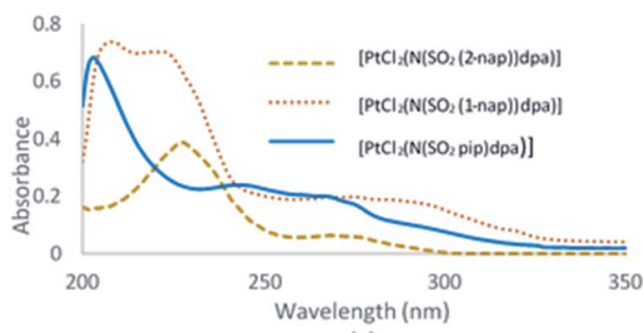

(a)

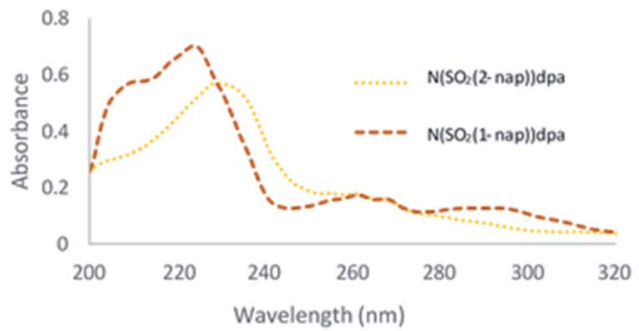

(b)

Fig. 3 UV-visible spectra of Pt complexes (a) and ligands (b). 


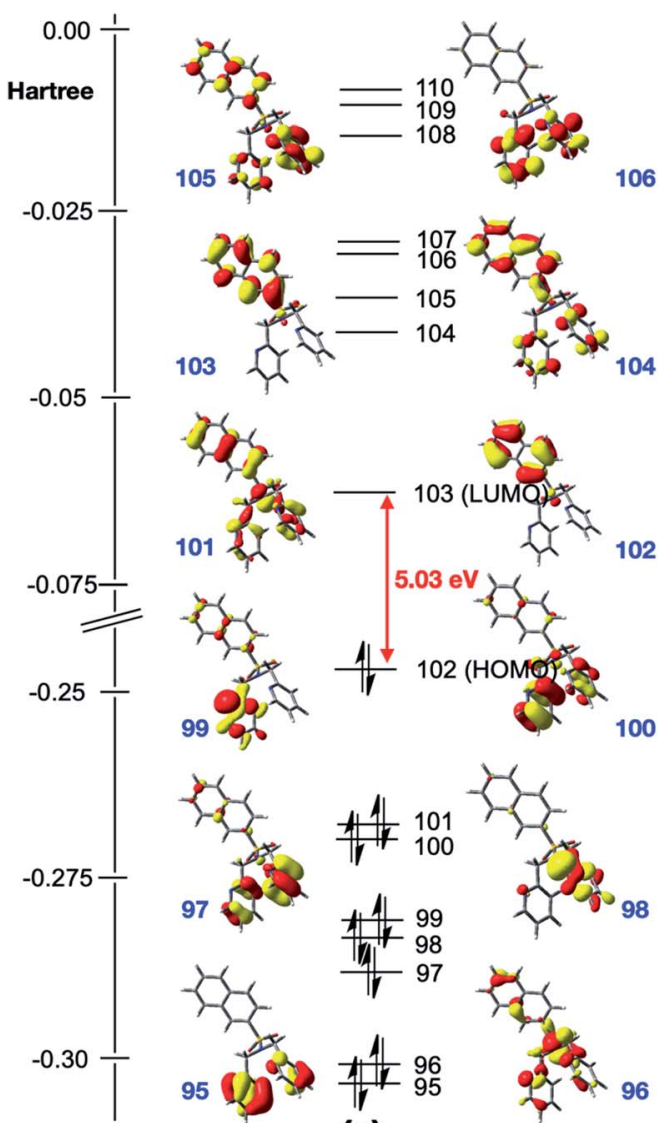

(a)

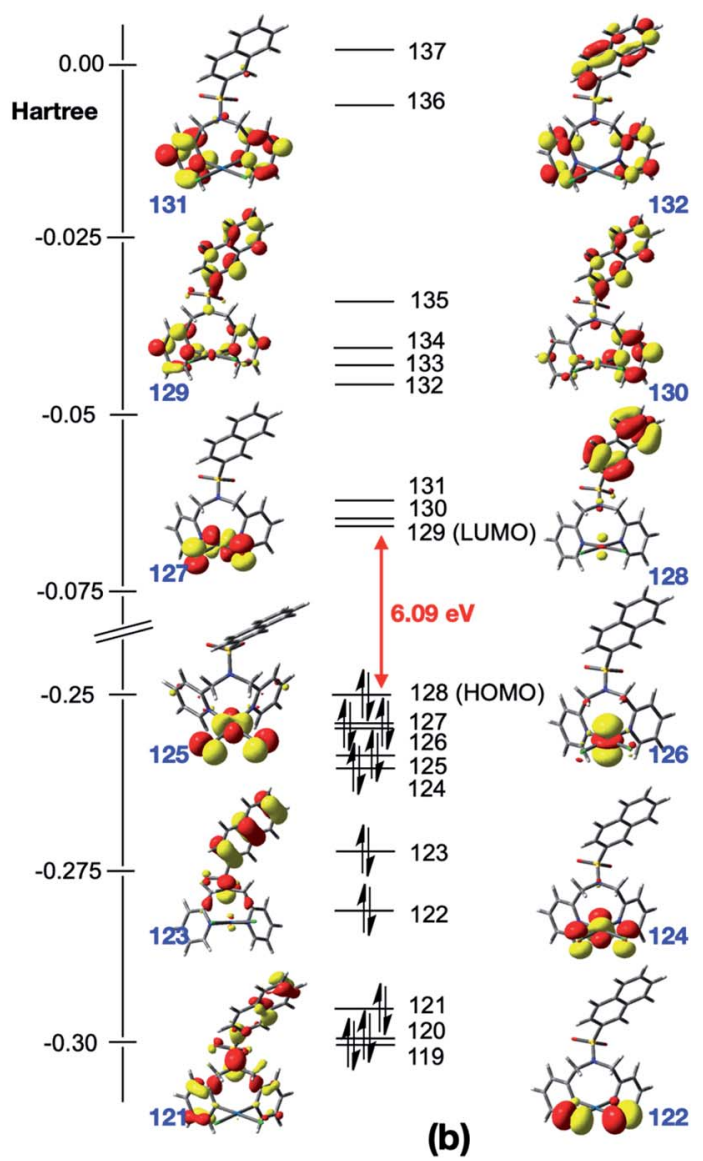

(b)

Fig. 4 Kohn-Sham frontier molecular orbitals of the optimized structures of (a) N(SO $2(2-n a p)) d p a$ and $(b)\left[\mathrm{PtCl}_{2}\left(\mathrm{~N}\left(\mathrm{SO}_{2}(2-n a p)\right) \mathrm{dpa}\right)\right]$.

Kohn-Sham frontier molecular orbitals of $\left[\mathrm{PtCl}_{2}\left(\mathrm{~N}\left(\mathrm{SO}_{2}\right.\right.\right.$ (1-nap)) $\mathrm{dpa})]$ and $\left[\mathrm{PtCl}_{2}\left(\mathrm{~N}\left(\mathrm{SO}_{2} \mathrm{pip}\right) \mathrm{dpa}\right)\right]$ complexes $)$. In both systems, the HOMO and LUMO are delocalized on the nap unit. Computed HOMO-LUMO gap of $\mathrm{N}\left(\mathrm{SO}_{2}(2-\mathrm{nap})\right) \mathrm{dpa}$ is $5.03 \mathrm{eV}$, and $\left[\mathrm{PtCl}_{2}\left(\mathrm{~N}\left(\mathrm{SO}_{2}\right.\right.\right.$ (2-nap))dpa) $]$ has a slightly higher HOMOLUMO gap (6.09 eV). For the $\mathrm{N}\left(\mathrm{SO}_{2}(2\right.$-nap))dpa system, calculated natural transition orbitals (NTO) indicated four types of $\pi$ $\rightarrow \pi^{*}$ excitations; (i) $\pi$ (nap) $\rightarrow \pi^{*}$ (nap) at $289 \mathrm{~nm}(f=0.06)$, (ii) $\pi$ (dpa) $\rightarrow \pi^{*}$ (nap) at $244 \mathrm{~nm}(f=0.24)$ and $243(f=0.30)$, (iii) $\pi$ (dpa) $\rightarrow \pi^{*}$ (dpa) at $223 \mathrm{~nm}\left(f=0.14\right.$ ), (iv) $\pi$ (nap) $\rightarrow \pi^{*}$ (dpa) at $211 \mathrm{~nm}(f=0.12)$. This is qualitatively in agreement with the experimental spectrum and previous studies. ${ }^{43}$ In the case of $\left[\mathrm{PtCl}_{2}\left(\mathrm{~N}\left(\mathrm{SO}_{2}\right.\right.\right.$ (2-nap))dpa) $]$ complex, NTOs indicated that the key excitations at $291 \mathrm{~nm}(f=0.05)$ and $279 \mathrm{~nm}(f=0.05)$ have metal to dpa ligand charge transfer character, while the excitation at $277 \mathrm{~nm}(f=0.0 .03)$ has the 2-nap-ligand-centered $\pi$ $\rightarrow \pi^{*}$ character, which is qualitatively in agreement with the experimental data (612 $\mathrm{nm}$ emission).

\subsection{Fluorometric analysis}

Fluorescence spectra were obtained for all six compounds (Table S3 $\dagger$ ) in methanol. The concentration of the test samples were approximately $0.01 \mathrm{~mol} \mathrm{dm}{ }^{-3}$ for the analysis. Fluorescence spectrum for $\mathrm{N}\left(\mathrm{SO}_{2}\right.$ pip $)$ dpa was previously reported. ${ }^{25}$ The compounds were excited in the UV range and emission spectra of Pt complexes were obtained with $\lambda_{\max }=275 \mathrm{~nm}$ (Fig. S1 $\dagger$ ). In addition to that, a small peak was observed at $757 \mathrm{~nm}$ for the three complexes (Table S3†).

We have calculated the lowest excited singlet state minima for $\mathrm{N}\left(\mathrm{SO}_{2}\right.$ (2-nap))dpa system, showing the emission at $354 \mathrm{~nm}$. This is in agreement with the experimental value $(343 \mathrm{~nm})$. Computed electron density difference between the singlet excited state minima and its ground state is shown in Fig. 5, which can be assigned as the 2-nap ligand-centered emission (i.e. ${ }^{1} \mathrm{LC}$ ).

\subsection{Bio assays}

3.6.1. Antiproliferative activity. Three ligands and three novel complexes were assayed for their antiproliferative activity in human breast cancer cells (MCF-7) and normal human breast cells (MCF-10A). In this study, the cell lines were exposed to synthesized compounds in a concentration gradient up to $100 \mathrm{mg} \mathrm{ml}^{-1}$ and the half maximal inhibitory concentration $\left(\mathrm{IC}_{50}\right)$ was determined for each compound. Cytotoxicity was measured with sulforhodamine $\mathrm{B}$ assay. The results are provided in Fig. 6.

Excitingly, all ligands and complexes show dose dependent antiproliferative activity against the MCF-7 human breast cancer cell line where $\mathrm{N}\left(\mathrm{SO}_{2}\right.$ (1-nap))dpa, $\mathrm{N}\left(\mathrm{SO}_{2}\right.$ (2-nap))dpa and $\mathrm{N}\left(\mathrm{SO}_{2}\right.$ pip)dpa show $\mathrm{IC}_{50}$ values of $92.0 \pm 0.06 \mu \mathrm{M}, 18.1 \pm 0.10$ $\mu \mathrm{M}$ and $21.2 \pm 0.10 \mu \mathrm{M}$, respectively. High level of cytotoxicity 


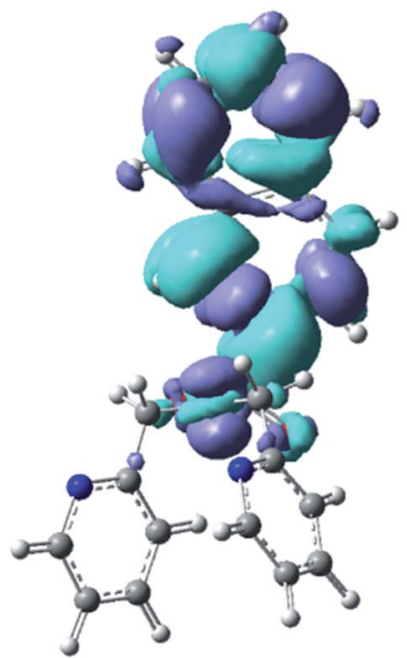

Fig. 5 Calculated electron density difference between the singlet excited state minima and its ground state of $\mathrm{N}\left(\mathrm{SO}_{2}(2-n a p)\right) d p a$ system.

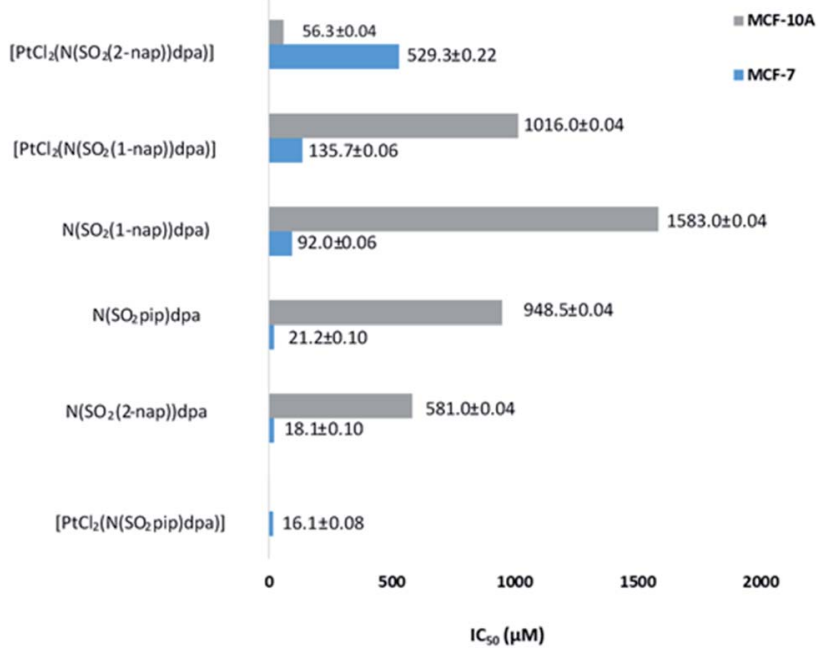

Fig. 6 Comparison of $I C_{50}$ values of the test compounds against human normal breast cells (MCF-10A) and human breast cancer cells (MCF-7).

demonstrated by the ligands against MCF-7 breast cancer cells shows their potential to be effective drug leads. Furthermore, their high potency for the usage as drug leads is strengthened by their lower toxicity towards MCF-10A normal human breast cells (N(SO $\left(1\right.$-nap))dpa) ( $\left.\mathrm{IC}_{50} 1583.0 \pm 0.04 \mu \mathrm{M}\right), \mathrm{N}\left(\mathrm{SO}_{2}\right.$ (2-nap)) dpa $\left(\mathrm{IC}_{50} 581.0 \pm 0.04 \mu \mathrm{M}\right)$ and $\mathrm{N}\left(\mathrm{SO}_{2} \mathrm{pip}\right) \mathrm{dpa}\left(\mathrm{IC}_{50} 948.5 \pm 0.04\right.$ $\mu \mathrm{M})$.

Interestingly, platinum complexation changes the dynamics of the ligands' behavior against the cancer cells as well as the normal cells. [ $\left.\mathrm{PtCl}_{2}\left(\mathrm{~N}\left(\mathrm{SO}_{2}(1-n a p)\right) \mathrm{dpa}\right)\right]$ compared to its ligand has low cytotoxicity against the MCF-7 but higher cytotoxicity against MCF-10A. Furthermore, $\mathrm{N}\left(\mathrm{SO}_{2}\right.$ (1-nap))dpa shows a biphasic cytotoxicity curve suggesting the involvement of multiple pathways in eliciting cytotoxic activity (Fig. S3†). The highest perturbation of ligand activity was observed with
$\mathrm{N}\left(\mathrm{SO}_{2}\right.$ (2-nap))dpa complexation with $\mathrm{Pt}$ where cytotoxicity against cancerous cells was lowered and a high cytotoxicity was mounted against MCF-10A non-cancerous cells. It can be hypothesized that complexation with Pt would lock and make the ligand conformationally rigid. Hence, its dynamic binding to the proteins or DNA/RNA can be perturbed. However, some ligands may get locked in the correct conformation, rendering them to be more effective once complexed with Pt acting synergistically. It is interesting to note that the $\mathrm{N}\left(\mathrm{SO}_{2}\right.$ pip)dpa ligand and its $\mathrm{Pt}$ complex display a high level of cytotoxicity against MCF-7 cells. Comparing the $\mathrm{IC}_{50}$ values at $24 \mathrm{~h}$ against MCF-7 breast cancer cell lines, $\left[\mathrm{PtCl}_{2}\left(\mathrm{~N}\left(\mathrm{SO}_{2}\right.\right.\right.$ pip)dpa $\left.)\right], \mathrm{N}\left(\mathrm{SO}_{2}\right.$ (2-nap))dpa, $\mathrm{N}\left(\mathrm{SO}_{2}\right.$ pip)dpa and $\left[\mathrm{PtCl}_{2}-\right.$ $\mathrm{N}\left(\mathrm{SO}_{2}\right.$ (1-nap))dpa] compounds exhibit higher toxicity than the reported value for cisplatin $(97.86 \mu \mathrm{M})$ (https://www.cancerrxgene.org/ translation/Drug/1005) which is a widely used anticancer drug. Further investigations are warranted to decipher the cellular mechanisms of cell death due to these compounds.

High antiproliferative activity implies the need of low concentrations of effective doses that may result in lower sideeffects in treatments. This assay system does not test for recurring cell proliferation after the drug pressure is lifted. However, at higher doses cells do not appear in the treatments indicating efficient removal of cancer cells. These findings emphasize that the above compounds have the potential to be promising anticancer drug leads.

\section{Conclusions}

Three novel Pt complexes were synthesized in good yield in high purity and characterized by various spectroscopic techniques. It is noteworthy that the splitting of the methylene $\left(-\mathrm{CH}_{2}\right)$ signal to doublets in NMR spectra is not indicative of the denticity of ligands containing the dpa sulfonamide moiety in platinum and rhenium complexes. Structural results of all three complexes established that a rare 8 -membered chelate ring is formed in each of the three complexes where the central sulfonamide $\mathrm{N}$ is not bound to Pt. X-ray structures are consistent with the optimized structures from DFT. TDDFT calculations indicated that, the key vertical excitations of $\mathrm{N}\left(\mathrm{SO}_{2}\right.$ (2-nap)) $\mathrm{dpa}$ and $\left[\mathrm{PtCl}_{2}\left(\mathrm{~N}\left(\mathrm{SO}_{2}(2\right.\right.\right.$-nap) $\left.\left.) \mathrm{dpa}\right)\right]$ involved the 2-nap-ligandcentered $\pi \rightarrow \pi^{*}$ excitation $\left({ }^{1} \mathrm{LC}\right)$. In the case of $\mathrm{N}\left(\mathrm{SO}_{2}(2-\right.$ nap))dpa, strong ${ }^{1} \mathrm{LC}$ emission leads to florescence.

We have reported here the first experimental results for anticancer activity for ligands containing the naphthyl dpa sulfonamide derivatives as well as for three novel platinum complexes where all compounds displayed positive anticancer activity. Low $\mathrm{IC}_{50}$ values obtained for ligands and complexes confirm that this moiety could indeed be explored towards finding new drugs which possess promising anticancer properties.

\section{Author contributions}

Nadini Thushara: investigation, formal analysis, methodology, data curation, writing original draft. Taniya Darshani: formal analysis, methodology. Sameera R. Samarakoon: investigation, resources, formal analysis, data curation. Inoka C. Perera: 
investigation, resources, formal analysis. Frank R. Fronczek: investigation, resources, formal analysis, data curation. W. M. C. Sameera: investigation, resources, formal analysis. Theshini Perera: methodology, conceptualization, supervision, writing review \& editing.

\section{Conflicts of interest}

The authors declare no conflict of interest regarding the publication of this paper.

\section{Acknowledgements}

We thank for the University of Sri Jayewardenepura for financial support (grant no. ASP/01/RE/SCI/2018/22). Authors gratefully acknowledge Prof. Luigi Marzilli and Dr Kokila Ranasinghe for help in obtaining NMR spectra and Ms Umapriyatharshini Rajagopalan for help with cell culture work. The Central Instrument Centre and Centre for Material Science, University of Sri Jayewardenepura are acknowledged. Super computing resources at the Academic Center for Computing at Media Studies at Kyoto University in Japan and the Institute of Molecular Science in Japan are also acknowledged.

\section{References}

1 B. K. Keppler, Metal complexes in cancer chemotherapy, wileyVCH, 1993.

2 D. E. Reichert, J. S. Lewis and C. J. Anderson, Coord. Chem. Rev., 1999, 184, 3-66.

3 B. L. Holman, A. G. Jones, J. Lister-James, A. Davison, M. J. Abrams, J. M. Kirshenbaum, S. S. Tumeh and R. J. English, J. Nucl. Med., 1984, 25, 1350-1355.

4 R. Schibli and A. P. Schubiger, Eur. J. Nucl. Med. Mol. Imaging, 2002, 29, 1529-1542.

5 M. F. Braña and A. Sánchez-Migallón, Clin. Transl. Oncol., 2006, 8, 717-728.

6 S. R. Lane, B. Veerendra, T. L. Rold, G. L. Sieckman, T. J. Hoffman, S. S. Jurisson and C. J. Smith, Nucl. Med. Biol., 2008, 35, 263-272.

7 J. Xia, Y. Wang, G. Li, J. Yu and D. Yin, J. Radioanal. Nucl. Chem., 2008, 279, 245-252.

8 R. M. R. Malone, Bioinorganic Chemistry: A Short Course, 2002.

9 B. Rosenberg, Biochimie, 1978, 60, 859-867.

10 B. Rosenberg, L. Van Camp, E. B. Grimley and A. J. Thomson, J. Biol. Chem., 1967, 242, 1347-1352.

11 I. Kostova, Recent Pat. Anti-Cancer Drug Discovery, 2006, 1, 122.

12 C. Monneret, Ann. Pharm. Fr., 2011, 69, 286-295.

13 V. Maheshwari, D. Bhattacharyya, F. R. Fronczek, P. A. Marzilli and L. G. Marzilli, Inorg. Chem., 2006, 45, 7182-7190.

14 M. Cusumano, M. L. Di Pietro, A. Giannetto and P. A. Vainiglia, J. Inorg. Biochem., 2005, 99, 560-565.

15 J. Reedijk, Eur. J. Inorg. Chem., 2009, 1303-1312.

16 N. Farrell, Comments Inorg. Chem., 1995, 16, 373-389.
17 J. Reedijk, Proc. Natl. Acad. Sci. U. S. A., 2003, 100, 3611-3616. 18 A. M. Christoforou, P. A. Marzilli and L. G. Marzilli, Inorg. Chem., 2006, 45, 6771-6781.

19 K. Ranasinghe, P. A. Marzilli, S. Pakhomova and L. G. Marzilli, Inorg. Chem., 2018, 57, 12756-12768.

20 J. Reedijk, Chem. Commun., 1996, 801-806.

21 V. Caveliers, H. Everaert, C. S. John, T. Lahoutte and A. Bossuyt, J. Nucl. Med., 2002, 43, 1647-1649.

22 V. Caveliers, H. Everaert, T. Lahoutte, L. O. Dierickx, C. S. John and A. Bossuyt, Eur. J. Nucl. Med. Mol. Imaging, 2001, 28, 133-135.

23 D. Satpati, K. Bapat, H. D. Sarma, M. Venkatesh and S. Banerjee, J. Labelled Compd. Radiopharm., 2010, 53, 198204.

24 K. Kawamura, P. H. Elsinga, T. Kobayashi, S.-i. Ishii, W.-F. Wang, K. Matsuno, W. Vaalburg and K. Ishiwata, Nucl. Med. Biol., 2003, 30, 273-284.

25 A. Subasinghe, I. C. Perera, S. Pakhomova and T. Perera, Bioinorg. Chem. Appl., 2016, 2016, 207-216.

26 B. L. Wilkinson, L. F. Bornaghi, A. D. Wright, T. A. Houston and S.-A. Poulsen, Bioorg. Med. Chem. Lett., 2007, 17, 13551357.

27 C. T. Supuran and A. Scozzafava, Expert Opin. Ther. Pat., 2000, 10, 575-600.

28 J.-P. Liou, K.-S. Hsu, C.-C. Kuo, C.-Y. Chang and J.-Y. Chang, J. Pharmacol. Exp. Ther., 2007, 323, 398-405.

29 A. E. Boyd, Diabetes, 1988, 37, 847-850.

30 M. M. Ghorab, F. A. Ragab, H. I. Heiba and R. M. El-Hazek, Eur. J. Med. Chem., 2011, 46, 5120-5126.

31 P. L. Abhayawardhana, P. A. Marzilli, F. R. Fronczek and L. G. Marzilli, Inorg. Chem., 2014, 53, 1144-1155.

32 T. Storr, C. L. Fisher, Y. Mikata, S. Yano, M. J. Adam and C. Orvig, Dalton Trans., 2005, 654-655.

33 T. Perera, P. Abhayawardhana, P. A. Marzilli, F. R. Fronczek and L. G. Marzilli, Inorg. Chem., 2013, 52, 2412-2421.

34 S. Makar, T. Saha and S. K. Singh, Eur. J. Med. Chem., 2019, 161, 252-276.

35 F. M. De Groot, W. J. Loos, R. Koekkoek, L. W. van Berkom, G. F. Busscher, A. E. Seelen, C. Albrecht, P. de Bruijn and H. W. Scheeren, J. Org. Chem., 2001, 66, 8815-8830.

36 S. Valente, D. Trisciuoglio, T. De Luca, A. Nebbioso, D. Labella, A. Lenoci, C. Bigogno, G. Dondio, M. Miceli and G. Brosch, J. Med. Chem., 2014, 57, 6259-6265.

37 C. Abate, M. Niso, E. Lacivita, P. D. Mosier, A. Toscano and R. Perrone, J. Med. Chem., 2011, 54, 1022-1032.

38 G. Laverty, A. P. McCloskey, B. F. Gilmore, D. S. Jones, J. Zhou and B. Xu, Biomacromolecules, 2014, 15, 3429-3439.

39 M. H. Huang, S. N. Wu, J. P. Wang, C. H. Lin, S. I. Lu, L. F. Liao and A. Y. Shen, Drug Dev. Res., 2003, 60, 261-269.

40 S. Biswas, S. Zhang, F. Fernandez, B. Ghosh, J. Zhen, E. Kuzhikandathil, M. E. Reith and A. K. Dutta, J. Med. Chem., 2008, 51, 101-117.

41 G.-J. Mao, T.-T. Wei, X.-X. Wang, S.-y. Huan, D.-Q. Lu, J. Zhang, X.-B. Zhang, W. Tan, G.-L. Shen and R.-Q. Yu, Anal. Chem., 2013, 85, 7875-7881.

42 J. H. Price, A. N. Williamson, R. F. Schramm and B. B. Wayland, Inorg. Chem., 1972, 11, 1280-1284. 
43 T. Darshani, N. Thushara, P. Weerasuriya, F. R. Fronczek, I. C. Perera and T. Perera, Polyhedron, 2020, 114592.

44 M. Frisch, G. Trucks, H. Schlegel, G. Scuseria, M. Robb and J. Cheeseman, Gaussian 16, 2016, p. 3.

45 J. P. Perdew, K. Burke and M. Ernzerhof, Phys. Rev. Lett., 1996, 77, 3865.

46 S. Grimme, S. Ehrlich and L. Goerigk, J. Comput. Chem., 2011, 32, 1456-1465.

47 T. H. Dunning and P. J. Hay, in Modern theoretical chemistry, Plenum Press, New York, 1977, vol. 3, p. 1.

48 P. Fuentealba, L. Szentpály, H. Stoll, F. Fraschio and H. Preuss, J. Mol. Struct.: THEOCHEM, 1983, 93, 213-219.

49 F. Weigend and R. Ahlrichs, Phys. Chem. Chem. Phys., 2005, 7, 3297-3305.

50 F. Weigend, Phys. Chem. Chem. Phys., 2006, 8, 1057-1065.

51 S. Miertuš, E. Scrocco and J. Tomasi, Chem. Phys., 1981, 55, 117-129.

52 S. Miertus and J. Tomasi, Chem. Phys., 1982, 65, 239-245.
53 J.-L. Pascual-ahuir, E. Silla and I. Tunon, J. Comput. Chem., 1994, 15, 1127-1138.

54 L. W. Chung, W. Sameera, R. Ramozzi, A. J. Page, M. Hatanaka, G. P. Petrova, T. V. Harris, X. Li, Z. Ke and F. Liu, Chem. Rev., 2015, 115, 5678-5796.

55 J. Pedregosa, G. Alzuet, J. Borras, S. Fustero, S. García-Granda and M. Diaz, Acta Crystallogr., Sect. C: Cryst. Struct. Commun., 1993, 49, 630-633.

56 W. Sameera and F. Maseras, J. Chem. Inf. Model., 2018, 58, 1828-1835.

57 A.-M. Häkkinen, P. Ruostesuo and R. Kivekäs, J. Chem. Soc., Perkin Trans. 2, 1988, 815-820.

58 R. D. Bindal, J. T. Golab and J. A. Katzenellenbogen, J. Am. Chem. Soc., 1990, 112, 7861-7868.

59 H. E. Gottlieb, V. Kotlyar and A. Nudelman, J. Org. Chem., 1997, 62, 7512-7515.

60 J. J. Wilson, J. Fedoce Lopes and S. J. Lippard, Inorg. Chem., 2010, 49, 5303-5315. 